\title{
ON-SITE TRAFFIC MANAGEMENT EVALUATION AND PROPOSALS TO IMPROVE SAFETY OF ACCESS TO WORKPLACES
}

Jozef Palo ${ }^{1, *}$, Ondrej Stopka ${ }^{2}$

${ }^{1}$ Department of Road and Urban Transport, Faculty of Operation and Economics of Transport and Communications, University of Zilina, Zilina, Slovak Republic

${ }^{2}$ Department of Transport and Logistics, Institute of Technology and Business in Ceske Budejovice, Ceske

Budejovice, Czech Republic

*E-mail of corresponding author: jozef.palo@fpedas.uniza.sk

\section{Resume}

Transport is a phenomenon currently used in almost every sector. That is why attention is to be paid to transport safety, which should not only be addressed in relation to situation in cities or urban areas, but it is also necessary to deal with transport safety in larger enterprises where motor traffic encounters non-motorized traffic. The authors elaborated a similar research study. The introductory two sections analyze the current situation in terms of identifying bottlenecks of the traffic organization on the industrial site and possible separation of motor from non-motorized traffic to ensure safe access to workplaces and improve safety of transport on the site. In the most important part of the study, the obtained results are presented, wherein the "load" of the individual entry and exit points is specified. Thereafter, based on the acquired data, particular solutions related to transport safety with appropriate discussion are proposed.

Available online: https://doi.org/10.26552/com.C.2021.3.A125-A136

\section{Article info}

Received 17 September 2020

Accepted 19 October 2020

Online 24 March 2021

\section{Keywords:}

traffic management, transport safety, access to workplace, manufacturing enterprise

ISSN 1335-4205 (print version) ISSN 2585-7878 (online version)

\section{Introduction}

Transport safety represents a fundamental issue for any state or region and public, as well as private, authorities concerned are confronted with a problem of identifying a certain location wherein the specific safety restrictions and improvement measures are to be undertaken [1]. The very aspects associated with the three elements of transport safety; i.e. driver, vehicle, transport infrastructure and its surroundings, are often evaluated and investigated by implementing a variety of advanced information systems and technologies and have an influence on the particular consideration of transport safety and quality [2-3].

Transport safety will continue to be a crucial issue for each society, especially for 1 the ow-income states. The most relevant aspects affecting a road safety level and hence, may be considered to be key attributes in the context of introducing specific safety measures are as follows [4-7]:

- parameters of route (foundation, slopes, curves, gradients, designed parameters for vehicles and so forth),

- parameters of an entrance to the area concerned (access point),

- parameters of vehicles,
- infrastructure maintenance level,

- infrastructure network saturation degree,

- location visibility,

- long-term and short-term weather conditions,

- drivers and population features,

- previous statistics of drivers associated with transport safety in the given territory,

- preferences and special requirements.

Analogous topics have been addressed in a series of publications presented by numerous authors. For instance, the subject of the traffic safety in terms of social and economic aspects, such as working conditions, job strain and driving accidents, is emphasized in [8] by Useche at al. by Meszaros et al. [9] and by Malka et al. [10].

As far as another similar aspect is concerned, literature sources [11-12] deal with an issue of traffic safety systems in water transport, while Jurkovic et al. designed an advanced technology to increase navigation safety encompassing a system for monitoring the life functions of a crew member, as well as a position of the vessel towards the fairway/shore [11], whereas Wang et al. [12] tried to eliminate a risk of occupational hazards and thus improve safety conditions when strengthening hazard knowledge and enhancing safety behavior for water port employees. 


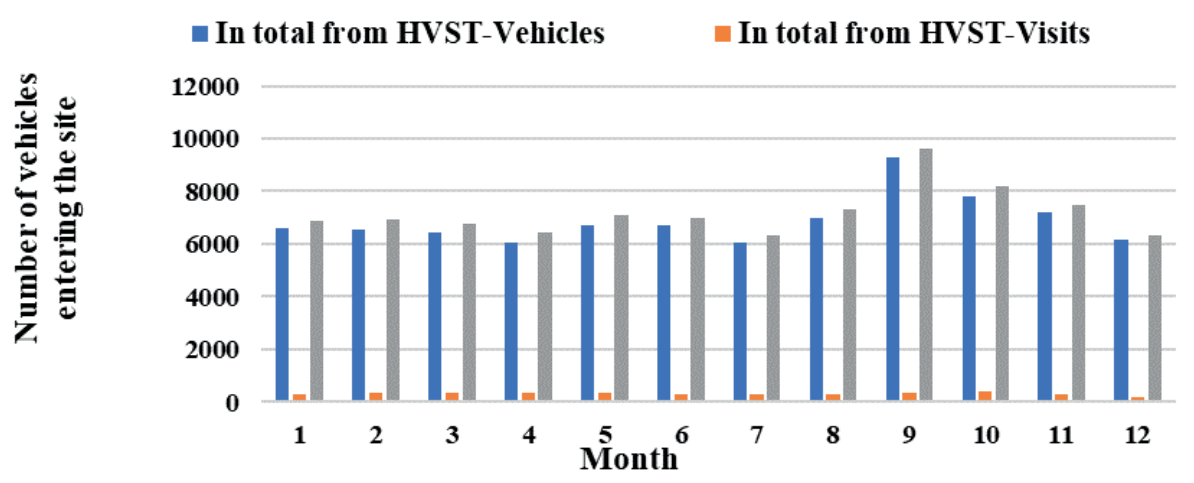

Figure 1 Number of vehicles entering the site through the main entrance in the reference period

Table 1 Daily average of vehicles entering the site through the main gate (HVST-overall)

\begin{tabular}{ccccccccc}
\hline day of the Week & Monday & Tuesday & Wednesday & Thursday & Friday & $\begin{array}{c}\text { Saturday } \\
\text { Sunday }\end{array}$ & $\begin{array}{c}\text { total daily average for } \\
5 \text { days of the week in the } \\
\text { reference period }\end{array}$ \\
$\begin{array}{c}\text { total daily } \\
\text { average in the } \\
\text { reference period }\end{array}$ & 303.7 & 333.75 & 334.82 & 317.4 & 277.6 & 43.8 & 39.1 & 313.6 \\
\hline
\end{tabular}

On the other hand, in publications [6, 13-14], a topic concerning an effect of a human factor on generating the traffic congestions is analyzed. Lizbetin and Bartuska were focused on creation of the traffic congestions, specifically on urban roads, wherein they confirm that the driver reaction (perception) time affects a number as well as an extent of such congestions [6]. In relation to manuscript [13], Kubanova and Poliakova highlighted importance of scheduling the truck-driver time, as one of the essential elements associated with the transport safety. As for Useche et al., their practical research study [14] investigates a relation between the stress-creating work conditions of bus-rapid-transport drivers and risky driving behaviors, as well as looks into whether fatigue entails a factor intermediating a relationship between these two attributes.

Even Posuniak et al. elaborated related publication, in which they presented the restraint safety systems for children (i.e. booster seats) when carrying in vehicles [15]. In particular, they conducted several experiments when utilizing child dummies under simulated traffic circumstances to better comprehend an impact on both the traffic dynamics and kinematics of the technology being applied.

And last but not least, description of different techniques for vehicle data detection used when the road traffic counting, during the largest traffic survey conducted in the Czech Republic, focused mainly on the traffic safety data, is outlined in article compiled by Hanzl et al. [16].

\section{Data and methods}

The objective of this manuscript is to analyze the current state on the specific industrial site regarding the traffic organization, identify potential bottlenecks in this particular regard and thereafter, propose possible scenarios in terms of separating motor from non-motorized traffic, as well as streamlining parking situation in order to secure safe access to individual workplaces and enhance transport safety on this site.

To this end, as alternative methods to be applied, following recommendations for their implementation into the examined industrial site are presented in the next sections of this research study: a) classification of roads and pathways on the site to secure better traffic management resulting in a more favorable orientation of drivers and pedestrians; b) design of a new parking area for heavy trucks to eliminate traffic jams currently emerging on the main road); c) design of new parking bays allowing vehicles to wait for handling while not obstructing the free passage of other vehicles; d) separation of road transport from pedestrians; i.e. establishment of a new pathway method for more convenient orientation of employees.

As for the access to workplace, regarding the examined enterprise, the main entrance (hereinafter referred to as HVST) is designed for employees, contractors, visitors and vehicles up to 3.5 tones. Persons enter the site through turnstiles 1 to 5 at the gate and only one person passes through in the car - the driver. The modified data set includes a breakdown of incoming vehicles into vehicles of visitors (hereinafter referred to as HVST-Visits) and other vehicles (hereinafter referred to as HVST-Vehicles) [17].

During the reference (examined) period, it was identified that about the same number of vehicles entered the site through the main entrance, which is over 6,000 vehicles per month, with a daily average of more than 200 vehicles (see Figure 1). However, these 


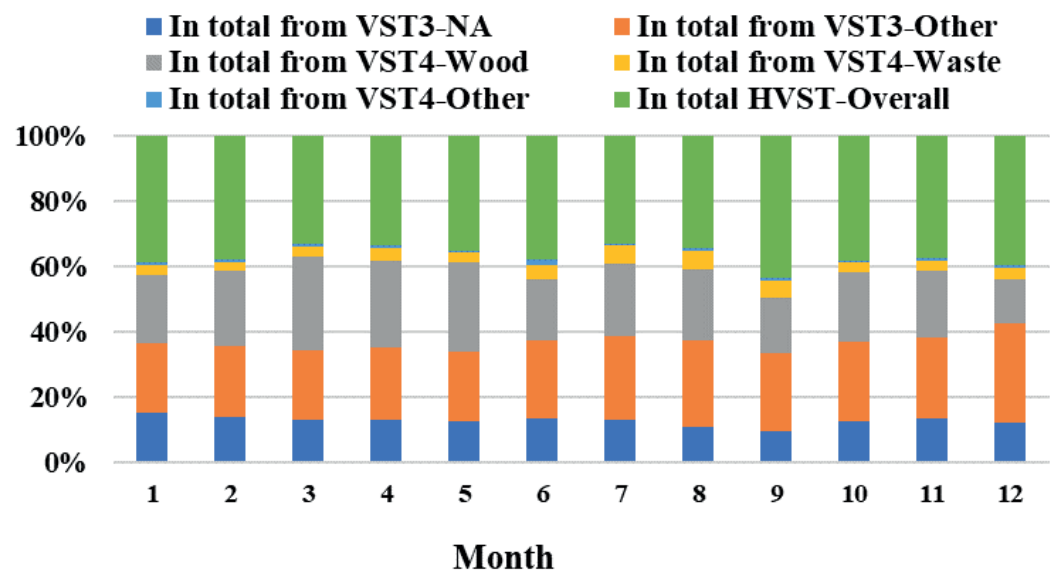

Figure 2 Percentage of vehicles per site entrance investigated in the reference period

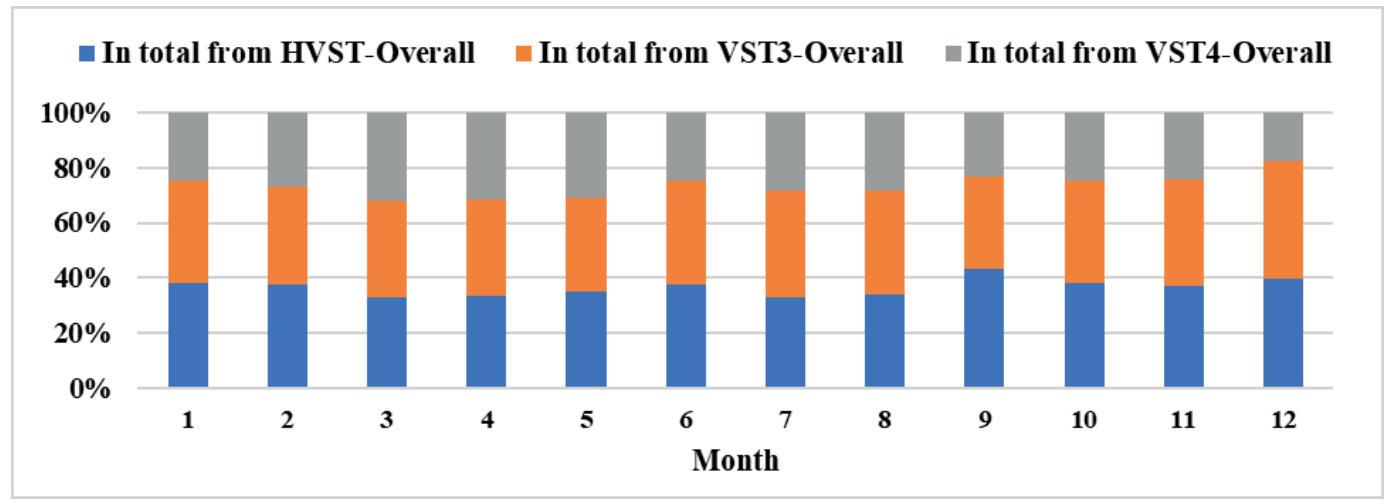

Figure 3 Percentage of the sum of all the vehicles per site entrance investigated in the reference period

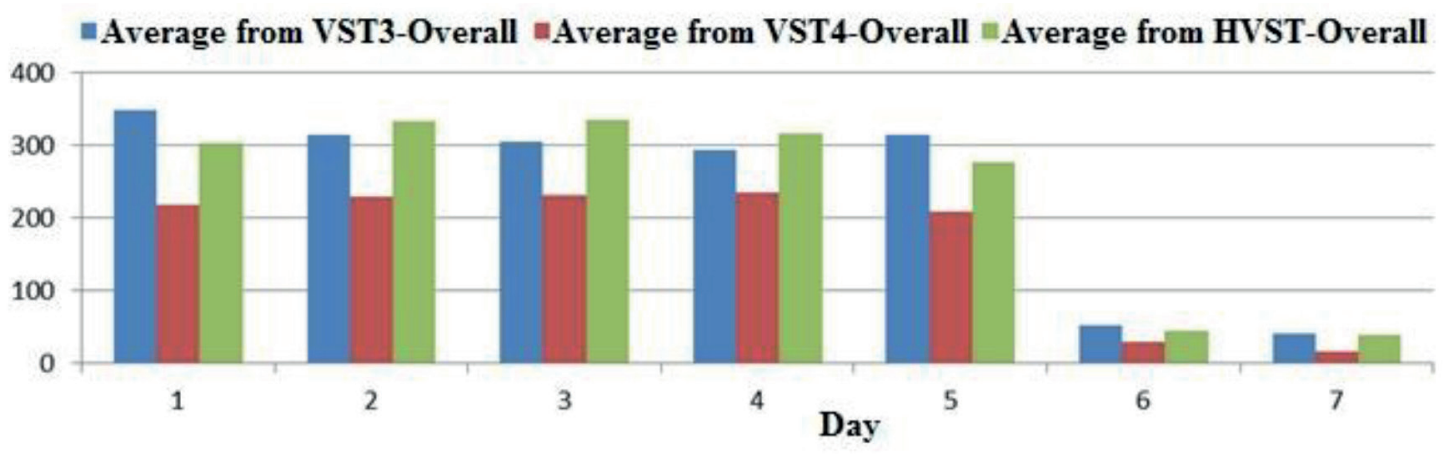

Figure 4 Daily average of vehicles per site entrance investigated in the reference period by day

values are affected by a significant decline in vehicles on Saturday and Sunday.

That is why the daily average of vehicles passing through the main entrance every day of the week is also provided (see Table 1). The daily average in the reference period was 300 vehicles from Monday to Friday with Tuesday and Wednesday (330 vehicles) being the busiest days and with a partial decline on Monday (300 vehicles) and especially on Friday (280 vehicles). The average on Saturday and Sunday was 40 vehicles.

In addition to the main entrance, two other entrance gates on the site, identified as entrance 3 (in figures and tables, referred to as VST3) and entrance 4 (in figures and tables, referred to as VST4) of the enterprise, were considered. Based on the processed data, Table 2 provides statistical evaluation of those entrances during the reference period [18-19]. As far as the number of vehicles during the reference period is concerned, entrance 3 with a total of 86,535 vehicles was the most occupied, followed by the main entrance with 86,347 vehicles and entrance 4 with a total of 62,820 vehicles.

The percentage of vehicles entering the site per entrance and month of the reference period is shown in Figures 2 and 3.

The overall data shows that this percentage does not even change with the day of the week [19].

The daily average of vehicles entering the site through the entrances investigated on each day of the week is shown in the following Figure 4. The average of 300 vehicles enter the site through entrance 3 and 
Table 2 Number of vehicles entering the site through the entrances investigated

\begin{tabular}{ccccccccccc}
\hline month & VST3-NA & $\begin{array}{c}\text { VST3- } \\
\text { other }\end{array}$ & $\begin{array}{c}\text { VST3- } \\
\text { overall }\end{array}$ & $\begin{array}{c}\text { VST4- } \\
\text { wood }\end{array}$ & $\begin{array}{c}\text { VST4- } \\
\text { waste }\end{array}$ & $\begin{array}{c}\text { VST4- } \\
\text { other }\end{array}$ & $\begin{array}{c}\text { VST4- } \\
\text { overall }\end{array}$ & $\begin{array}{c}\text { HVST- } \\
\text { vehicles }\end{array}$ & $\begin{array}{c}\text { HVST- } \\
\text { visits }\end{array}$ & $\begin{array}{c}\text { HVST- } \\
\text { overall }\end{array}$ \\
\hline 01 & 2,770 & 3,846 & 6,616 & 3,747 & 560 & 163 & 4,470 & 6,592 & 293 & 6,885 \\
02 & 2,587 & 4,002 & 6,589 & 4,269 & 514 & 178 & 4,961 & 6,571 & 339 & 6,910 \\
03 & 2,681 & 4,440 & 7,121 & 5,857 & 640 & 125 & 6,622 & 6,419 & 351 & 6,770 \\
04 & 2,552 & 4,249 & 6,801 & 5,079 & 829 & 113 & 6,021 & 6,058 & 363 & 6,421 \\
05 & 2,569 & 4,391 & 6,960 & 5,577 & 620 & 120 & 6,317 & 6,734 & 369 & 7,103 \\
06 & 2,546 & 4,399 & 6,945 & 3,486 & 778 & 316 & 4,580 & 6,690 & 310 & 7,000 \\
07 & 2,513 & 4,945 & 7,458 & 4,300 & 1,087 & 120 & 5,507 & 6,059 & 271 & 6,330 \\
08 & 2,394 & 5,652 & 8,046 & 4,684 & 1,204 & 232 & 6,120 & 7,006 & 312 & 7,318 \\
09 & 2,147 & 5,328 & 7,475 & 3,741 & 1,228 & 171 & 5,140 & 9,266 & 341 & 9,607 \\
10 & 2,783 & 5,177 & 7,960 & 4,641 & 597 & 157 & 5,395 & 7,787 & 381 & 8,168 \\
11 & 2,687 & 5,032 & 7,719 & 4,072 & 646 & 124 & 4,842 & 7,177 & 312 & 7,489 \\
12 & 2,003 & 4,842 & 6,845 & 2,177 & 586 & 102 & 2,845 & 6,147 & 199 & 6,346 \\
\hline in total & 30,232 & 56,303 & 86,535 & 51,630 & 9,289 & 1,921 & 62,820 & 82,506 & 3,841 & 86,347 \\
\hline
\end{tabular}

Table 3 Number of personnel using the access points at a distance of less than $500 \mathrm{~m}$

\begin{tabular}{|c|c|c|c|c|c|c|}
\hline \multirow[t]{2}{*}{ no. } & \multirow[t]{2}{*}{ description } & \multirow[t]{2}{*}{$\begin{array}{l}\text { distance from the main } \\
\text { entrance in meters }\end{array}$} & \multicolumn{4}{|c|}{$\begin{array}{l}\text { number of employees } \\
\text { using the given entrance }\end{array}$} \\
\hline & & & shift 1 & shift 2 & shift 3 & shift 4 \\
\hline 5 & PM 16 - material preparation plant & 100 & 22 & 10 & 6 & 6 \\
\hline 6 & $\begin{array}{l}\text { channel storage system of finished goods } \\
\text { PS } 16 / 17\end{array}$ & 145 & 6 & 6 & & \\
\hline 1 & finished goods store & 200 & 30 & 11 & & \\
\hline 37 & electric motor store & 200 & 2 & & & \\
\hline 8 & $\begin{array}{l}\text { treatment plant for PS } 7 \text { - processing } \\
\text { machine hall }\end{array}$ & 217 & 31 & 20 & 8 & 8 \\
\hline 2 & PS 1 - preparation plant & 218 & 23 & 12 & & \\
\hline 7 & $\begin{array}{l}\text { administrative building of the timberyard } \\
+ \text { workshops }\end{array}$ & 260 & 5 & 0 & & \\
\hline 10 & $\begin{array}{l}\text { timberyard - decortication and cutting } \\
\text { machines ANDRITZ }\end{array}$ & 409 & 22 & 11 & 11 & \\
\hline 12 & near mechanical workshops & 477 & 5 & 0 & & \\
\hline 11 & sanitation facilities & 478 & 3 & 0 & & \\
\hline \multirow[t]{2}{*}{13} & mechanical workshops & 500 & 23 & 2 & & \\
\hline & & total & 172 & 72 & 25 & 14 \\
\hline
\end{tabular}

the main entrance daily from Monday to Friday and the average of over 200 vehicles through entrance 4 .

\section{Use of the main entrances to the site by pedestrians}

A breakdown of workplaces by distance from the main entrance was based on the available data [13]. Table 3 shows workplaces at a distance of less than $500 \mathrm{~m}$ from the main entrance - a total of 11 workplaces. Table 4 shows workplaces at a distance of $500 \mathrm{~m}$ to $1,000 \mathrm{~m}$ from the main entrance - 10 workplaces. Table 5 shows workplaces at a distance of more than $1,000 \mathrm{~m}$ from the main entrance - 10 workplaces. Two "unattended" workplaces and two workplaces with zero number of employees were not included in calculations. In addition, the office building (3) with the largest number of employees (300) of all the workplaces was not considered, since this building is not accessed through the main entrance [20]. In addition, the administrative building (97) was not considered, since it is used for training of contractors - the west entrance from the parking lot or the east entrance to the site for the foreign language courses.

Consequently, tabular data is presented graphically for all the shifts (see Figure 5).

Based on the analysis of the input data (number of employees, the expected financial investments, etc.), a proposal may be made to prioritize repairs/ 
Table 4 Number of personnel using the access points at a distance of $500 \mathrm{~m}$ to $1,000 \mathrm{~m}$

\begin{tabular}{|c|c|c|c|c|c|c|}
\hline \multirow[t]{2}{*}{ no. } & \multirow[t]{2}{*}{ description } & \multirow[t]{2}{*}{$\begin{array}{l}\text { distance from the main } \\
\text { entrance in meters }\end{array}$} & \multicolumn{4}{|c|}{$\begin{array}{l}\text { number of employees } \\
\text { using the given entrance }\end{array}$} \\
\hline & & & shift 1 & shift 2 & shift 3 & shift 4 \\
\hline 14 & mechanical maintenance workshops & 550 & 17 & 6 & & \\
\hline 15 & chemical store & 600 & 1 & 1 & & \\
\hline 17 & COV - chemical water treatment plant & 650 & 1 & 1 & 1 & \\
\hline 16 & celpap warehouses + new cafeteria & 680 & 5 & 0 & & \\
\hline 18 & COV - operations building & 740 & 32 & 7 & 7 & \\
\hline 19 & control room of the cooking plant & 760 & 15 & 5 & & \\
\hline 20 & administrative building of the pulp mill & 900 & 36 & 2 & & \\
\hline 21 & boiler house (RK1 + KB) & 972 & 38 & 12 & 12 & \\
\hline 27 & workshops and locker room & 997 & 4 & 1 & & \\
\hline \multirow[t]{2}{*}{28} & water treatment plant & 1,000 & 5 & 2 & & \\
\hline & & total & 154 & 37 & 20 & 0 \\
\hline
\end{tabular}

Table 5 Number of personnel using the access points at a distance of more than 1,000 m

\begin{tabular}{|c|c|c|c|c|c|c|}
\hline \multirow[t]{2}{*}{ no. } & \multirow[t]{2}{*}{ description } & \multirow[t]{2}{*}{$\begin{array}{l}\text { distance from the main } \\
\text { entrance in meters }\end{array}$} & \multicolumn{4}{|c|}{$\begin{array}{c}\text { number of employees } \\
\text { using the given entrance }\end{array}$} \\
\hline & & & shift 1 & shift 2 & shift 3 & shift 4 \\
\hline 25 & paper processing plant PM18 & 1,300 & 65 & 30 & & \\
\hline 26 & solo packaging & 1,300 & 25 & 8 & & \\
\hline 23 & paper making machine hall PM 18 & 1,400 & 31 & 11 & 9 & 9 \\
\hline 31 & warehouses & 1,400 & 3 & & & \\
\hline 33 & porter's lodge - entrance CIII & 1,400 & 3 & 3 & & \\
\hline 34 & finished goods store PM 18 & 1,400 & 13 & 6 & & \\
\hline 32 & spare part store & 1,500 & 6 & & & \\
\hline 35 & dock and workshop & 1,550 & 3 & 0 & & \\
\hline 30 & fire station - SD-pallets & 1,600 & 17 & 12 & 4 & \\
\hline \multirow[t]{2}{*}{36} & entrance gate for vehicles & 1,954 & 4 & & & \\
\hline & & total & 170 & 70 & 13 & 9 \\
\hline
\end{tabular}

Number of personnel depending on distance of the workplace from the main entrance- all shifts

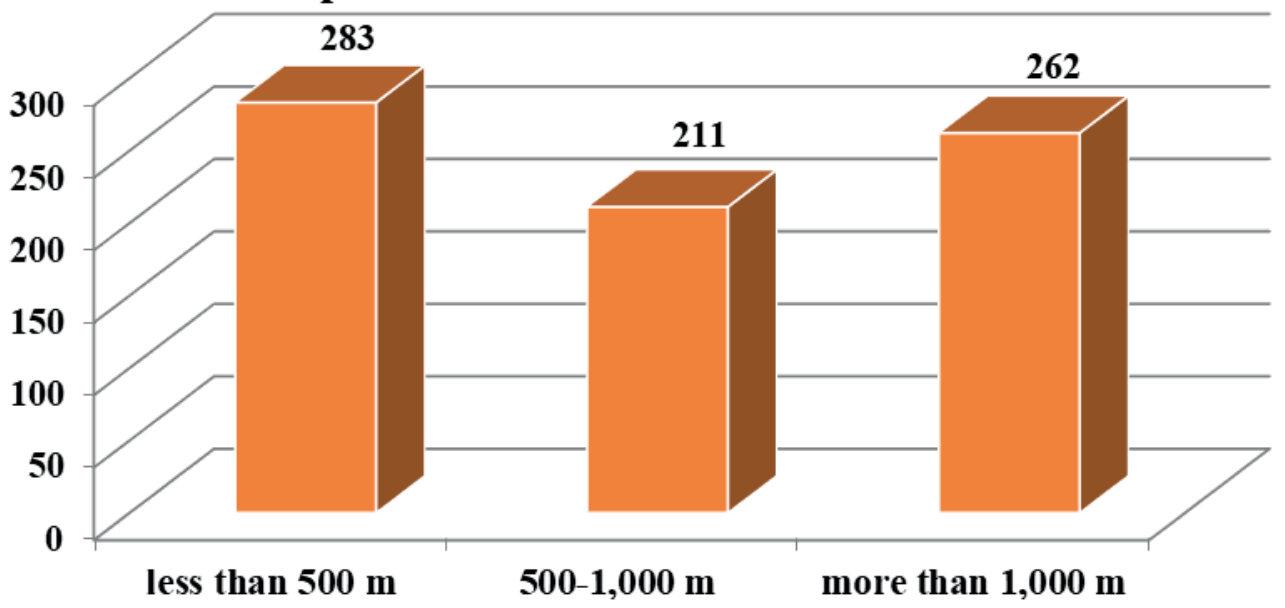

Figure 5 Number of personnel depending on distance of the workplace from the main entrance - all shifts 
Table 6 Workplaces with more than 20 employees

\begin{tabular}{|c|c|c|c|c|c|c|}
\hline \multirow[t]{2}{*}{ no. } & \multirow[t]{2}{*}{ description } & \multirow[t]{2}{*}{$\begin{array}{l}\text { distance from the main } \\
\text { entrance in meters }\end{array}$} & \multicolumn{4}{|c|}{$\begin{array}{l}\text { number of employees } \\
\text { using the given entrance }\end{array}$} \\
\hline & & & shift 1 & shift 2 & shift 3 & shift 4 \\
\hline 25 & paper processing plant PM18 & 1,300 & 65 & 30 & & \\
\hline 21 & boiler house (RK1 + KB) & 972 & 38 & 12 & 12 & \\
\hline 20 & $\begin{array}{l}\text { administrative building of the pulp } \\
\text { mill }\end{array}$ & 900 & 36 & 2 & & \\
\hline 18 & COV - operations building & 740 & 32 & 7 & 7 & \\
\hline 23 & paper making machine hall PM 18 & 1,400 & 31 & 11 & 9 & 9 \\
\hline 8 & $\begin{array}{l}\text { treatment plant for PS } 7 \text { - processing } \\
\text { machine hall }\end{array}$ & 217 & 31 & 20 & 8 & 8 \\
\hline 1 & finished goods store & 200 & 30 & 11 & & \\
\hline 26 & solo packaging & 1,300 & 25 & 8 & & \\
\hline 13 & mechanical workshops & 500 & 23 & 2 & & \\
\hline 2 & PS 1 - preparation plant & 218 & 23 & 12 & & \\
\hline 10 & $\begin{array}{l}\text { timberyard - decortication and } \\
\text { cutting machines ANDRITZ }\end{array}$ & 409 & 22 & 11 & 11 & \\
\hline
\end{tabular}

Table 7 Number of pedestrians and vehicles moving through the main entrance and entrance 3 during week

\begin{tabular}{|c|c|c|c|c|c|c|c|}
\hline \multirow[b]{2}{*}{ day of the week } & \multicolumn{3}{|c|}{ pedestrians } & \multicolumn{2}{|c|}{ vehicles } & \multirow[b]{2}{*}{ VST3 /O } & \multirow[b]{2}{*}{ Total } \\
\hline & VST1 01 & VST1 02 & VST1 /P & VST1 /O & VST3 /P & & \\
\hline 1 & 1,135 & 1,070 & 314 & 314 & 384 & 359 & 3,576 \\
\hline 2 & 1,217 & 1,143 & 319 & 342 & 371 & 334 & 3,726 \\
\hline 3 & 1,253 & 1,195 & 336 & 349 & 374 & 356 & 3,863 \\
\hline 4 & 1,333 & 1,226 & 345 & 368 & 303 & 263 & 3,838 \\
\hline 5 & 1,085 & 1,056 & 269 & 263 & 287 & 273 & 3,233 \\
\hline 6 & 578 & 574 & 39 & 36 & 48 & 37 & 1,312 \\
\hline 7 & 13 & 52 & 29 & 32 & 46 & 29 & 201 \\
\hline total & 6,614 & 6,316 & 1,651 & 1,704 & 1,813 & 1,651 & 19,749 \\
\hline weekly average Monday-Friday & $1,204.6$ & 1,138 & 316.6 & 327.2 & 343.8 & 317 & \\
\hline
\end{tabular}

constructions of pavements leading to the workplaces at a distance of less than $500 \mathrm{~m}$, or the most occupied roads. In the next stage, the workplaces at a distance of over $500 \mathrm{~m}$, or cycling solutions for workplaces at a distance of more than $1,000 \mathrm{~m}$ can be provided.

\section{Use of the existing roads and pavements by pedestrians}

To evaluate how the existing roads and pavements are used by pedestrians, workplaces with more than 20 employees in the first shift were selected. The largest number of employees is in the PM18 Paper Processing Plant (25). There are 65 employees in the first shift and this also applies to the second shift with 30 employees as illustrated in Table 6. The most occupied part of the road accounts for 160 employees in the first shift. This road should be prioritized to take into consideration a possible construction of a separate pavement [10].

Table 6 does not include workplaces where the roads investigated are not used and workplaces with less than 20 employees in the first shift.

\section{Analysis of the most occupied access points for vehicles and pedestrians}

The data obtained from an analysis of the most occupied access points for vehicles and pedestrians is provided here. Persons who access the site through the main entrance are hereinafter referred to as VST1 01 and persons who exit the site through the main entrance as VST1 02 and cars entering $(\mathrm{P})$ or exiting $(\mathrm{O})$ the site.

Table 7 summarizes values concerning a number of pedestrians and vehicles entering and exiting the site through the main entrance and entrance 3 during one selected week. Figure 6 depicts all the values regarding a number of pedestrians and vehicles entering and exiting the site through the main entrance and entrance 3 by days [21-23].

The analysis identifies the largest number of 


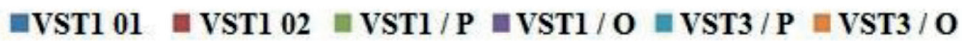

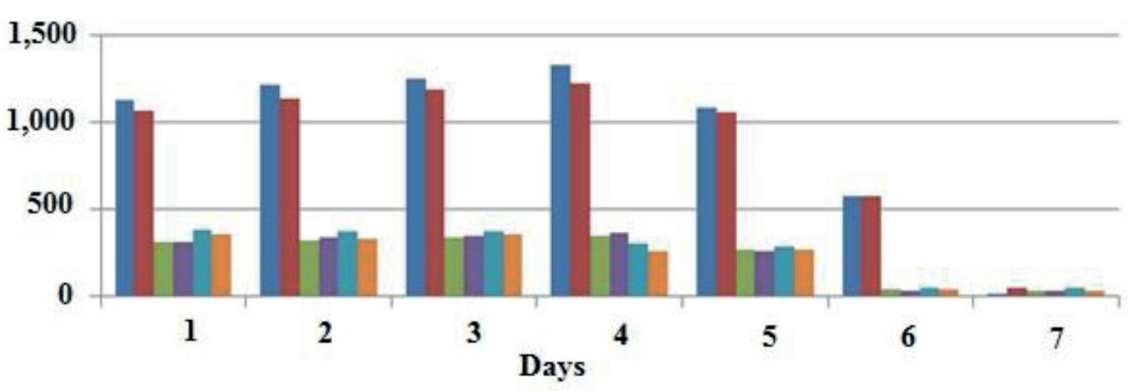

Figure 6 Number of pedestrians and vehicles entering and exiting the site through the main entrance and entrance 3 - by days

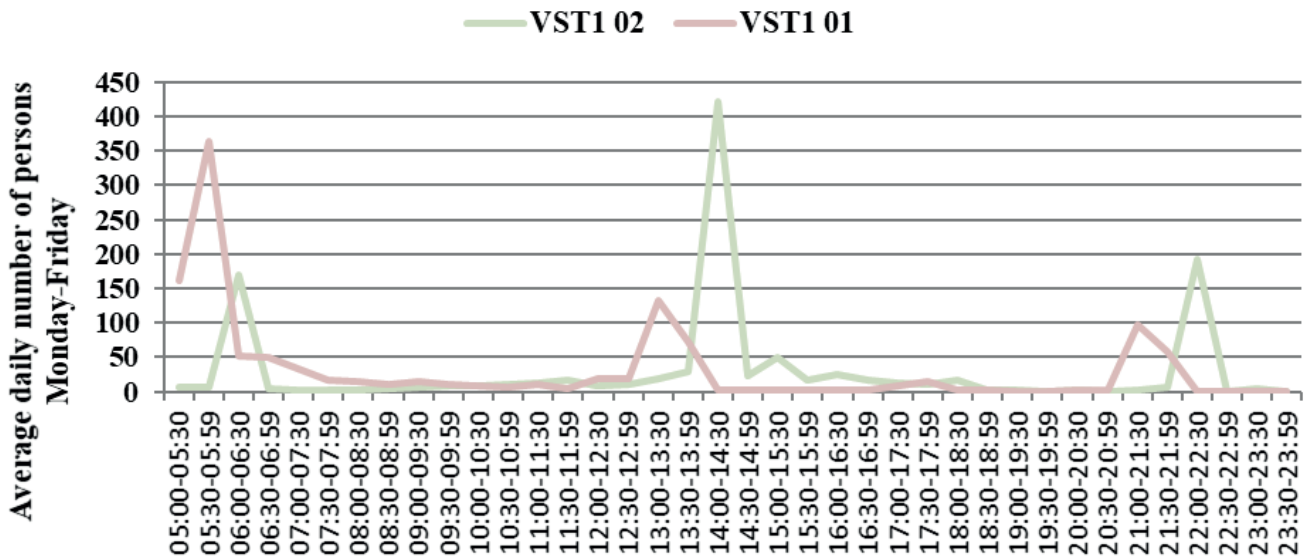

Figure 7 Average daily number of persons entering (01) and exiting (02) the site through the main entrance from Monday to Friday

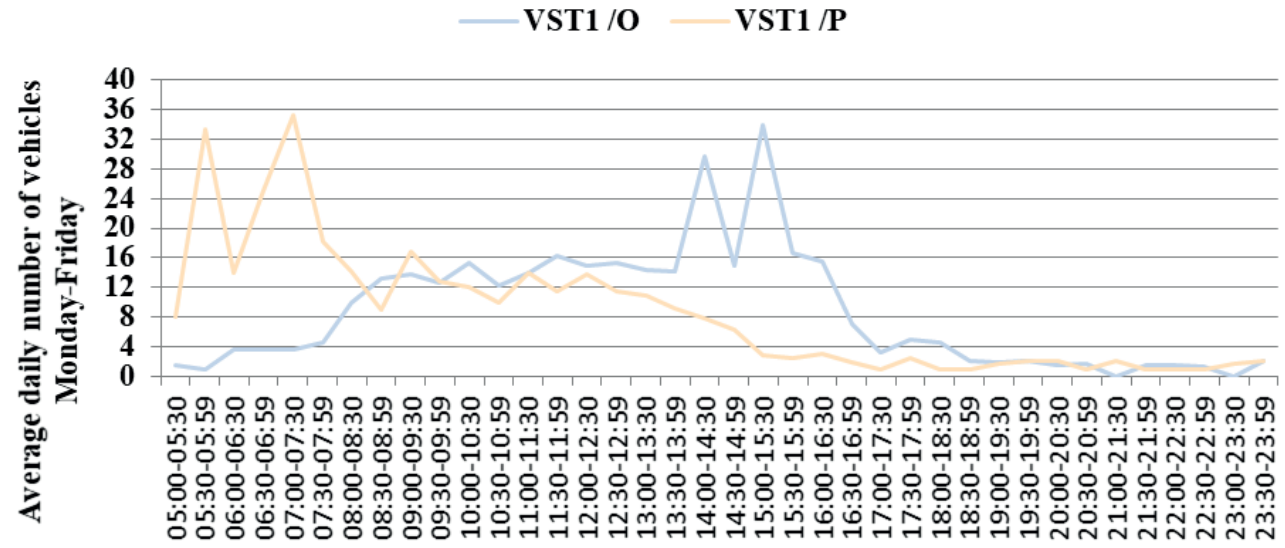

Figure 8 Average daily number of vehicles entering $(P)$ and exiting $(O)$ the site through the main entrance from Monday to Friday

persons with a weekly entry/exit average from Monday to Friday, namely persons who access the site - 1,204.6 and persons who exit the site - 1,138. The daily average is more than 300 vehicles entering and exiting the site through the main entrance and entrance 3.

Consequently, this data was analyzed in more detail at 30-minute intervals to determine the most exposed times regarding the number of persons who access the site through the main entrance. The most occupied time was specified the shift turnover at 5-7 a.m. where more than 600 people entered the site and 1-2 p.m. with more than 200 people, followed by 9-10 p.m. with more than 150 people. In regard to exit the site, more than 160 people left at 6-6.30 a.m., more than 500 people at 1:303:30 p.m. and more than 190 people at 10-10:30 p.m.

The detailed results obtained, i.e. quantification of average daily values, are depicted in Figures 7 to 9 .

As for the access through the main entrance, more than 100 vehicles on average entered the site between 5:30 and 7:30 a.m.; later, this number decreased and stagnated until 2 p.m. Thereafter, this number dropped rapidly. Regarding the exit of the site, most of the 


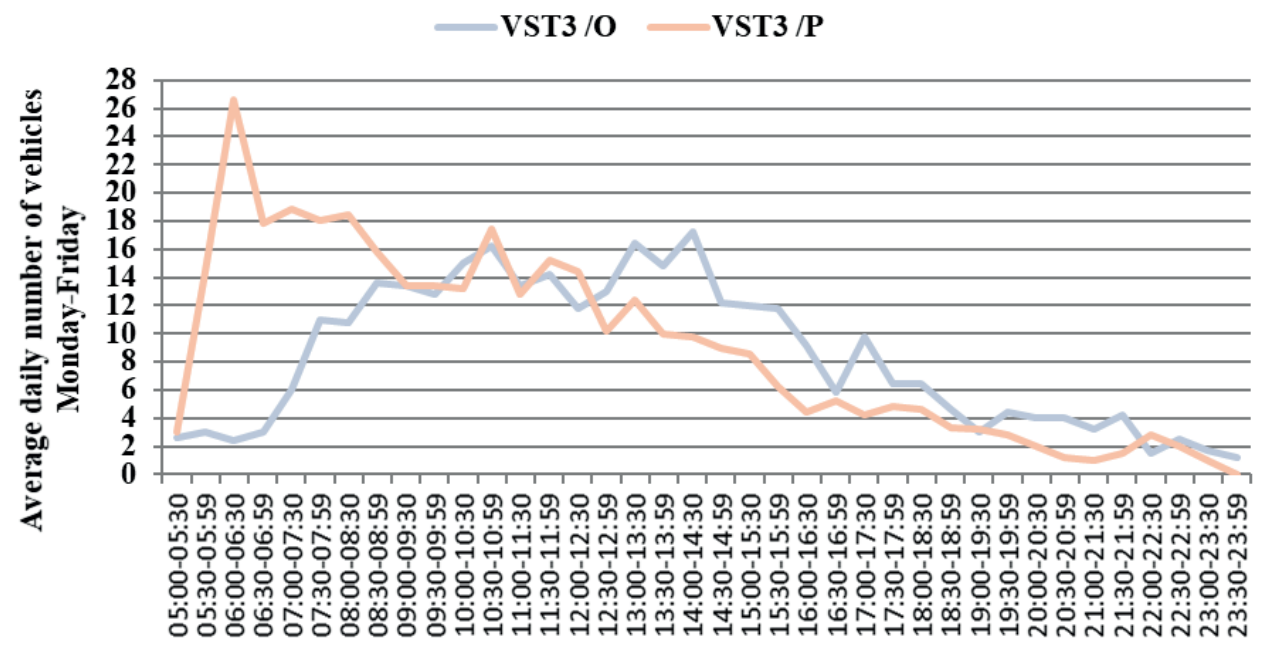

Figure 9 Average daily number of vehicles entering $(P)$ and exiting $(O)$ the site through entrance 3 from Monday to Friday

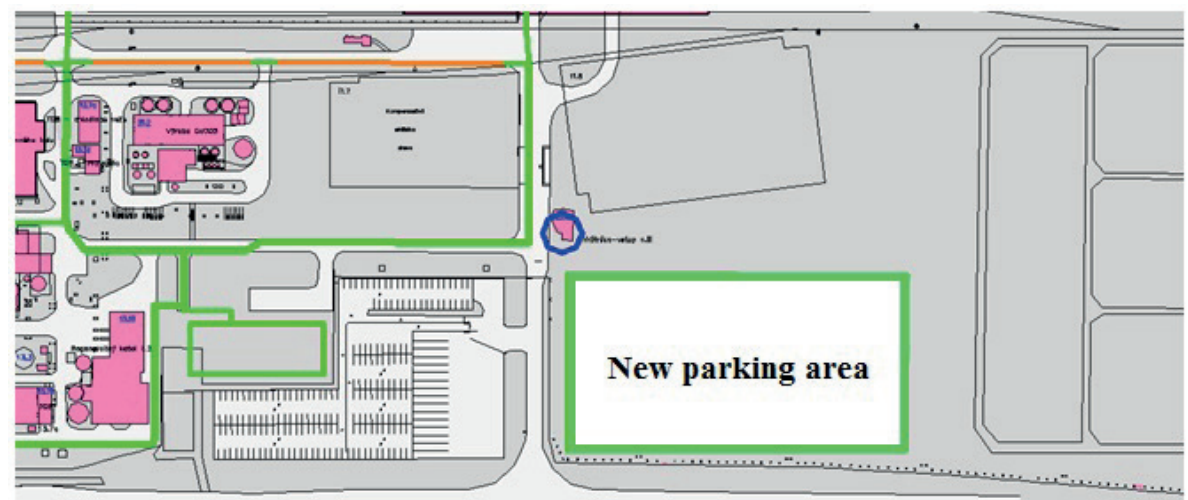

Figure 10 Proposed parking area for heavy trucks nearby entrance 3

vehicles left the site at 2-3:30, specifically more than 75 .

Concerning the access through entrance 3 , most of the vehicles (more than 40) entered the site between 5:30 and 7:30 a.m. Then, the average was of 18 vehicles in 30 minutes until 8:30 a.m. and later, more than 10 vehicles in 30 minutes until 1:59 p.m. After 2:00 p.m., the number of vehicles entering the site decreased and stagnated until the end of the day. In terms of exiting the site, the number of vehicles increased starting at 7 a.m., with the first peak from 10.30 to 10:59 a.m. - more than 16 vehicles in 30 minutes with a similar number of vehicles exiting the site again between 1:00-1:30 and 2:00-2:30 p.m.

\section{Proposals to improve transport and discussion}

This section consists of specific scenarios set towards improving the current state related to transport safety.

A. Systematic Marking of On-site Roads and Pathways Considering the differentiation among different road functions and in a view of existing and expected traffic intensity and safety, for the examined manufacturing enterprise, it is recommended to classify roads and pathways on the site in order to provide easier orientation and traffic management. It will require, for example, to assign names and characteristics and determine main and secondary roads and provide markings of important building numbers for on-site roads, e.g. loading points and so on. The systematic markings will support a possible incorporation of roads in navigation solutions, better orientation of drivers and other similar benefits [16, 24].

\section{B. Parking of Trucks Waiting in Front of Entrance 3}

Vehicle queues currently occur because of trucks waiting for entering the site on the existing road in front of entrance 3 . The idea of moving trucks entering loading points on the site to public car parks near the industrial site is rather difficult. There is not a suitable parking place downtown for a larger number of heavy trucks. Nearby petrol stations do not have a sufficient capacity to play the role of a parking lot [25].

To this end, a temporary or permanent parking area for heavy trucks (see Figure 10) is suggested to be used/built on the side of the current porter's lodge III. The very parking area should be dimensioned to allow enough space in order to avoid queues on the existing 


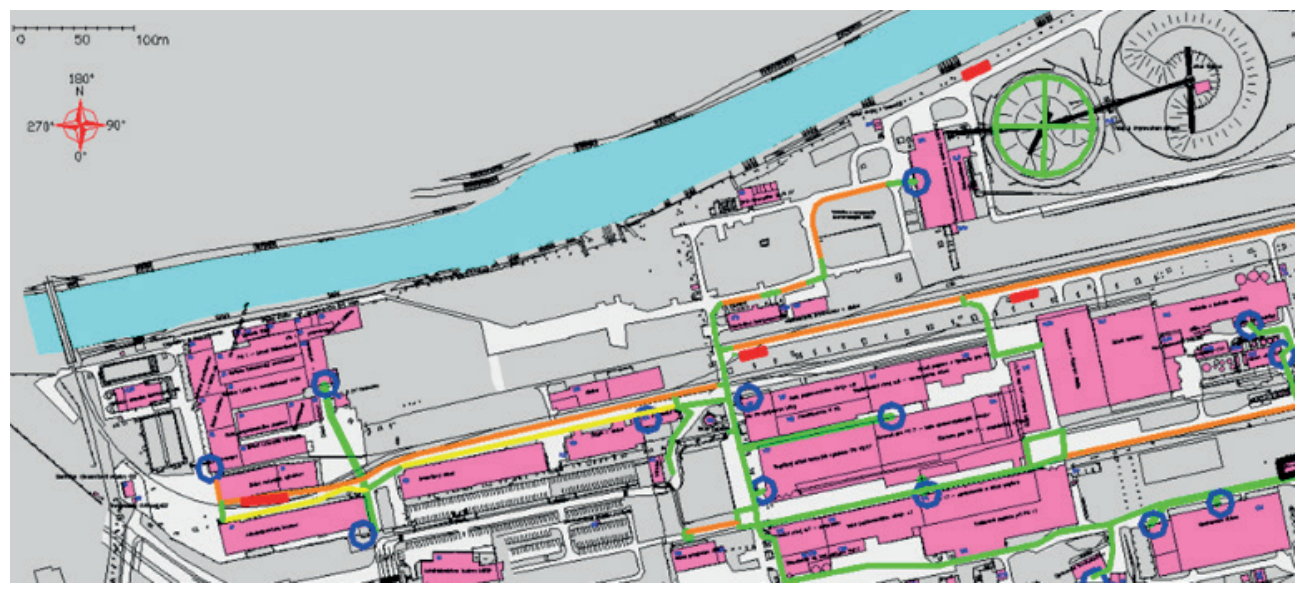

Figure 11 Recommended location for parking bays for trucks

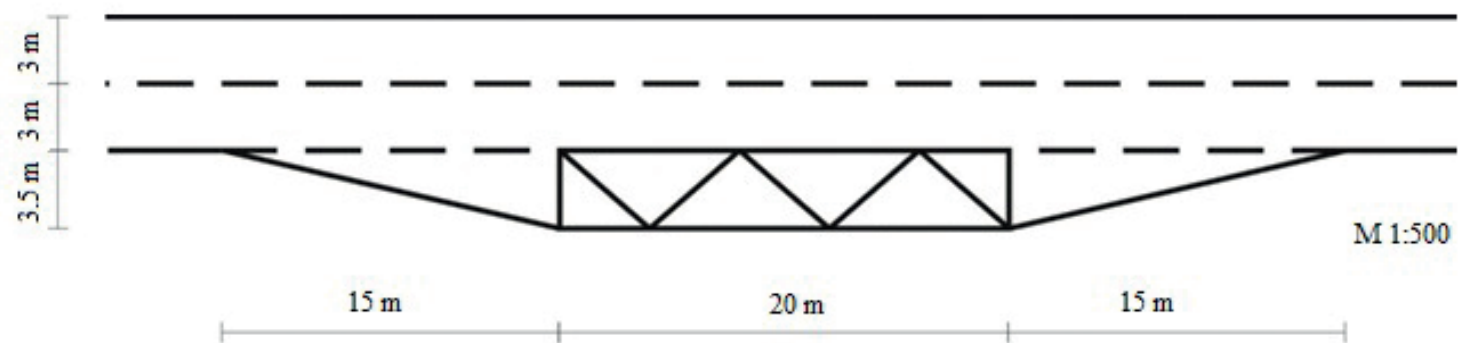

Figure 12 Scenario of a parking for articulated vehicles

road. Better material storage management in this area can create an additional space for a new parking area [26].

An alternative scenario for the heavy trucks parking area along the road (the main access to the town) is to build a parallel parking lot, which should eliminate traffic jams that currently emerge on the main road [19, 27].

\section{Parking Bays on the Site}

Currently, trucks are sometimes waiting for loading or unloading on several on-site roads. A solution would be to create parking bays allowing vehicles to wait for handling while not obstructing free passage of other vehicles (see Figure 11).

Parking areas for the road vehicles are designed in compliance with the technical standard STN 736056 where, however, dimensions for parking of articulated vehicles are not specified. Figure 12 illustrates a designed parking bay for such trucks. The width of the parking bay may also be reduced to $3 \mathrm{~m}$.

\section{Separation of Road Transport from Pedestrians}

The current situation in terms of marking of sidewalks (pathways) was mapped based on the visual inspection of the industrial site. These are ensured by diagonal stripes, so called zebras along some roads. The current marking for pedestrians has many disadvantages such as it starts or leads to "nowhere" which may confuse pedestrians, as well as implementation of diagonal stripes is not appropriate with respect to form (confused with pedestrian crossings). That is why a new pathway design is to be implemented for employees who come to and leave work as well as those intervening between workplaces on the site [28-29].

To introduce the new horizontal road surface markings in the main transport area, it is recommended to use parallel stripes, each of $125 \mathrm{~mm}$ wide, for marking of the areas for pedestrians. In accordance with the standard STN 736110 [29], an one-way pedestrian lane should have a width of $0.75 \mathrm{~m}$, i.e. the recommended width of the pavement should be $1.50 \mathrm{~m}$ for both directions. At crossing points where pedestrians have to cross the roads, it is recommended to apply diagonal stripes, or a dashed line [29]. As far as marginal points of sidewalk are concerned, a horizontal pedestrian sign may be marked at the beginning and at the end, or at regular distances (approx. $20 \mathrm{~m}$ ) to highlight a reserved pedestrian area [30].

The safest scenario is to separate pedestrians so that pathways on the main pedestrian diagonals are situated on a separate body in the adjacent area and secondary pathways are situated in the main traffic area and provided with the suggested horizontal road surface markings [31].

\section{Conclusions}

The transport safety on the industrial site could be increased by implementing at least some of the above recommendations, in particular in relation to motor and 
non-motorized traffic, above all with the emphasis on pedestrian traffic. It would also be reasonable to improve, streamline and simplify the movement of vehicles on on-site roads and thus put towards shortening the timeperiod of stay of trucks on the site.

In general, safety can be defined as a circumstance without a real threat or danger. Nevertheless, it has different specifications depending on the industry or situation. With regard to transportation, safety is referred to as creating conditions for minimizing conflicts and disturbances of the traffic flow in a certain mode of transport.

As for the specific proposals to be implemented in the industrial site being investigated, they can be summarized as follows:

- classification of roads and pathways on the site to secure better traffic management resulting in a more favorable orientation of drivers as well as other psychological-positive benefits,

- construction of a new parking area for the heavy trucks in front of entrance 3 (see Figure 10) to avoid queues on the existing road (i.e. to eliminate traffic jams that currently emerge on the main road),

- construction of the new parking bays allowing vehicles to wait for handling while not obstructing free passage of other vehicles (see Figure 11),
- implementation of a new pathway design for employees so that pathways on the main pedestrian diagonals are situated on a separate body in the adjacent area and secondary pathways are situated in the main traffic area and provided with the suggested horizontal road surface markings.

Aforementioned definition could also be regarded as a formulation of the objective addressed in this research study that tried to meet with the proposed scenarios - to minimize or eliminate traffic conflict situations on the industrial site in the examined manufacturing enterprise.

\section{Acknowledgment}

Contribution has been prepared based on the grant: VEGA no. 1/0436/18 - Externalities in road transport, an origin, causes and economic impacts of transport measures.

This manuscript was supported within realization of the research project entitled "Autonomous mobility in the context of regional development LTC19009" of the INTER-EXCELLENCE program, the VES 19 INTERCOST subprogram.

\section{References}

[1] MUIR, C., NEWNAM, S., NEWSTEAD, S., BOUSTRAS, G. Challenges for safety intervention in emergency vehicle fleets: a case study. Safety Science [online]. 2020, 123, 104543. ISSN 0925-7535. Available from: https://doi.org/10.1016/j.ssci.2019.104543

[2] POLIAKOVA, B., SEMANOVA, S. The use of transport processes modelling in the freight transport company. In: 21th International Scientific on Conference Transport Means 2017: proceedings. 2017. ISSN 1822-296X, p. 913-918.

[3] CABAN, J., DROZDZIEL, P., VRABEL, J., SARKAN, B., MARCZUK, A., KRZYWONOS, L., RYBICKA, I. The research on ageing of glycol-based brake fluids of vehicles in operation. Advances in Science and Technology-Research Journal [online]. 2016, 10(32), p. 9-16. ISSN 2299-8624. Available from: https://doi.org/10.12913/22998624/65113

[4] BERGLAND, H., PEDERSEN, P. A. Efficiency and traffic safety with pay for performance in road transportation. Transportation Research Part B: Methodological [online]. 2019, 130, p. 21-35. ISSN 0191-2615. Available from: https://doi.org/10.1016/j.trb.2019.10.005

[5] JAGELCAK, J., KIKTOVA, M., STOPKOVA, M. The application of the verified gross mass of intermodal loading units in the conditions of the Slovak Republic. Nase More [online]. 2018, 65(4), p. 218-223. Available from: https://doi.org/10.17818/NM/2018/4SI.10

[6] LIZBETIN, J., BARTUSKA, L. The influence of human factor on congestion formation on urban roads. Procedia Engineering [online]. 2017, 187, p. 206-211. ISSN 1877-7058. Available from: https://doi.org/10.1016/j. proeng.2017.04.366

[7] VIVODA, J. M., PRATT, S. G., GILLIES, S. J. The relationships among roadway safety management practices, collision rates and injury rates within company fleets. Safety Science [online]. 2019, 120, p. 589-602. ISSN 0925-7535. Available from: https://doi.org/10.1016/j.ssci.2019.07.033

[8] USECHE, S. A., GOMEZ, V., CENDALES, B., ALONSO, F. Working conditions, job strain and traffic safety among three groups of public transport drivers. Safety and Health at Work [online]. 2018, 9(4), p. 454-461. ISSN 2093-7911. Available from: https://doi.org/10.1016/j.shaw.2018.01.003

[9] MESZAROS, F., MARKOVITS-SOMOGYI, R., BOKOR, Z. Modelling and multi-criteria optimization of road traffic flows considering social and economic aspects. LOGI - Scientific Journal on Transport and Logistics [online]. 2012, 3(1), p. 70-82. ISSN 1804-3216, eISSN 2336-3037. 
[10] MALKA, R. A., LEIBOVITZ-ZUR, S., NAVEH, E. Employee safety single vs. dual priorities: When is the rate of work-related driving accidents lower? Accident Analysis and Prevention [online]. 2018, 121, p. 101-108. ISSN 0001-4575. Available from: https://doi.org/10.1016/j.aap.2018.08.020

[11] JURKOVIC, M., KALINA, T., TURCAN, R., GARDLO, B. Proposal of an enhanced safety system on board of the inland vessel. MATEC Web of Conferences [online]. 2017, 134, 00022. eISSN 2261-236X. Available from: https://doi.org/10.1051/matecconf/201713400022

[12] WANG, Y., ZHAN, S., LIU, Y., LI, Y. Occupational hazards to health of port workers. International Journal of Occupational Safety and Ergonomics [online]. 2017, 23(4), p. 584-588. ISSN 1080-3548, EISSN 2376-9130. Available from: https://doi.org/10.1080/10803548.2016.1199501

[13] KUBANOVA, J., POLIAKOVA, B. Truck driver scheduling of the rest period as an essential element of safe transport. In: 20th International Scientific on Conference Transport Means 2016: proceedings. 2016. ISSN 1822-296X, pp. 22-26.

[14] USECHE, S. A., ORTIZ, V. G., CENDALES, B. E. Stress-related psychosocial factors at work, fatigue and risky driving behavior in bus rapid transport (BRT) drivers. Accident Analysis and Prevention [online]. 2017, 104, p. 106-114. ISSN 0001-4575. Available from: https://doi.org/10.1016/j.aap.2017.04.023

[15] POSUNIAK, P., JASKIEWICZ, M., KOWALSKI, K., DABROWSKI, F. Child restraint systems: problems related to the safety of children transported in booster seats (without integral safety belts). In: 11th International Scientific and Technical Conference on Automotive Safety: proceedings. 2018.

[16] HANZL, J., BARTUSKA, L., LUPTAK, V. Traffic counts on roads in the Czech Republic. In: 23rd International Scientific Conference on Transport Means 2019: proceedings. 2019. ISSN 1822-296X, p. 1346-1350.

[17] MAKAROVA, I., SHUBENKOVA, K., BUYVOL, P., MAVRIN, V., GINIYATULLIN, I., MAGDIN, K. Safety features of the transport system in the transition to industry 4.0. The Archives of Automotive Engineering Archiwum Motoryzacji [online]. 2019, 86(4), p. 79-99. eISSN 2084-476X. Available from: https://doi.org/10.14669/ AM.VOL86.ART6

[18] OLUWASEYI, J. A., ONIFADE, M. K., ODEYINKA, O. F. Evaluation of the role of inventory management in logistics chain of an organisation. LOGI - Scientific Journal on Transport and Logistics [online]. 2017, 8(2), p. 1-11. ISSN 1804-3216, eISSN 2336-3037. Available from: https://doi.org/10.1515/logi-2017-0011

[19] CERNICKY, L., KALASOVA, A., MIKULSKI, J. Simulation software as a calculation tool for traffic capacity assessment. Communications - Scientific Letters of the University of Zilina [online]. 2016, 18(2), p. 99-103. ISSN 1335-4205, eISSN 2585-7878. Available from: http://komunikacie.uniza.sk/index.php/communications/ article/view/338

[20] RANI, H. A., ISYA, M., IQBAL, M. Risk level analysis of work safety and health on national road routine maintenance project using self-management system. IOP Conference Series: Materials Science and Engineering [online]. 2018, 674(1). ISSN 1757-899X, eISSN 1757-8991. Available from: https://doi.org/10.1088/1757899X/674/1/012013

[21] CHOVANCOVA, M., KLAPITA, V. Modeling the supply process using the application of selected methods of operational analysis. Open Engineering [online]. 2017, 7, p. 50-54. eISSN 2391-5439. Available from: https://doi.org/10.1515/eng-2017-0009

[22] STERNAD, M., SKRUCANY, T., JEREB, B. International logistics performance based on the DEA analysis. Communications - Scientific Letters of the University of Zilina [online]. 2018, 20(4), p. 10-15. ISSN 1335-4205, eISSN 2585-7878. Available from: https://doi.org/10.26552/com.C.2018.4.10-15

[23] DROZDZIEL, P., KOMSTA, H., KRZYWONOS, L. Repair costs and the intensity of vehicle use. Transport Problems. 2018, 8(3), p. 131-138. ISSN 1896-0596.

[24] WISHART, D., SOMORAY, K., EVENHUIS, A. Thrill and adventure seeking in risky driving at work: the moderating role of safety climate. Journal of Safety Research [online]. 2017, 63, p. 83-89. ISSN 0022-4375. Available from: https://doi.org/10.1016/j.jsr.2017.08.007

[25] FEDORKO, G., MOLNAR, V., HONUS, S., NERADILOVA, H., KAMPF, R. The application of simulation model of a milk run to identify the occurrence of failures. International Journal of Simulation Modelling [online]. 2018, 17, p. 444-457. ISSN 1726-4529. Available from: https://doi.org/10.2507/IJSIMM17(3)440

[26] YORK BIGAZZI, A., ROULEAU, M. Can traffic management strategies improve urban air quality? A review of the evidence. Journal of Transport and Health [online]. 2017, 7, p. 111-124. ISSN 2214-1405. Available from: https://doi.org/10.1016/j.jth.2017.08.001

[27] KUBASAKOVA, I., JAGELCAK, J. Logistics system just-in-time and its implementation within the company. Communications - Scientific Letters of the University of Zilina [online]. 2016, 18(2), p. 109-112. ISSN 1335-4205, eISSN 2585-7878. Available from: http://komunikacie.uniza.sk/index.php/communications/article/view/340

[28] KAMPF, R., HITKA, M., LIZBETINOVA, L. Direction of the corporate culture in Slovak and German transport companies from a top managers' perspective. Periodica Polytechnica Transportation Engineering [online]. 2019, 47, p. 213-219. ISSN 0303-7800, eISSN 1587-3811. Available from: https://doi.org/10.3311/PPtr.11166 
[29] ONDRUS, J., KARON, G. Video system as a psychological aspect of traffic safety increase. In: 17th International Conference on Transport Systems Telematics TST 2017: proceedings. Vol. 715. 2017. p. 167-177.

[30] GNAP, J., POLIAK, M., SEMANOVA, S. The issue of a transport mode choice from the perspective of enterprise logistics. Open Engineering [online]. 2019, 9(1), p. 374-383. eISSN 2391-5439. Available from: https://doi.org/10.1515/eng-2019-0044

[31] MORAVCIK, L., JASKIEWICZ, M. Boosting car safety in the EU. In: 11th International Scientific and Technical Conference on Automotive Safety: proceedings. 2018. 